\title{
ANALISIS FAKTOR- FAKTOR YANG MEMPENGARUHI KESEHATAN MENTAL EMOSIONAL MASYARAKAT DI DUKUH GUMUK SARI DAN GERJEN, PUCANGAN, KARTASURA
}

\author{
Tunjung Sri Yulianti, Dinar Ariasti \\ STIKES PANTI KOSALA SURAKARTA, Sukoharjo, Jawa Tengah, Indonesia
}

\begin{abstract}
Abstrak
Latar Belakang. Kesehatan jiwa atau kesehatan mental emosional adalah kondisi seseorang yang terus tumbuh berkembang dan mempertahankan keselarasan dalam pengendalian diri, serta terbebas dari stres yang serius. Kemajuan teknologi membawa perubahan gaya hidup masyarakat dan perubahan cara berfikir yang membawa konsekuensi pada kesehatan jiwa karena tidak semua orang mampu menyesuaikan diri, akibatnya akan menimbulkan ketegangan dan kecenderungan peningkatan gangguan kesehatan jiwa. Di Indonesia, jumlah kasus gangguan jiwa terus bertambah yang berdampak pada penambahan beban negara dan penurunan produktivitas manusia.

Tujuan. Mengetahui faktor-faktor yang mempengaruhi kesehatan mental emosional masyarakat.

Subyek dan Metode. Subjek adalah warga Dukuh Gumuk Sari dan Gerjen, Pucangan, Kartasura. Jenis penelitian analitik dengan desain korelasi. Uji statistik dengan regresi logistik.

Hasil. Terdapat pengaruh faktor somatik ( $p=0,001$ dan $O R=50,708)$, faktor sosial budaya $(p=0,004$ dan $O R=7,054)$ serta faktor psikologis $(p=0,058$ dan $O R=3,800)$ terhadap kesehatan mental emosional masyarakat.

Kesimpulan. Faktor somatik, sosial budaya dan psikologis secara bersama-sama berpengaruh terhadap kesehatan mental emosional masyarakat. Faktor somatik memiliki pengaruh paling besar terhadap kesehatan mental emosional responden.
\end{abstract}

Kata kunci: kesehatan mental emosional, psikologis, somatik, sosial budaya

\section{ANALYSIS OF FACTORS THATINFLUENCE THE MENTAL EMOTIONAL HEALTH OF THE COMMUNITY AT GUMUK SARI AND GERJEN HAMLET, PUCANGAN, KARTASURA}

\author{
Tunjung Sri Yulianti, Dinar Ariasti
}

\begin{abstract}
Background. Mental health or mental emotional health is a condition of someone who continues to grow and maintain harmony in self-control, and free from serious stress. Advances in technology bring changes in people's lifestyle and change in way of thinking that have consequences in mental health because not everyone can adjust, the result will be to couse tension and a tendency to increase mental health disorders. In Indonesia the number of cases of mental disorderes continues to grow which has an impact on increasing the country's burden and decreasing human productivity.

The Aim of the Study. To determine the factors that influence the mental emotional health of the community.

Subject and Method. The subjects were residents of Dukuh Gumuk Sari and Gerjen, Pucangan, Kartasura. This is analytic research with correlation design, statistical test with logistic regression.

Results. There is an influence of somatic factors ( $p$ value $=0.000$ and $O R=50,708$ ), sociocultural factors $(p$ value $=0.004$ and $O R=7,054)$ and psychological factors ( $p$ value $=$ 0.058 and $O R=3,800$ ) on mental emotional health of the community.

Conclusion. Somatic, socio-cultural and psychologic factors together have an influence on the emotional mental health of the community. Somatic factors have the greatest
\end{abstract}


influence on the emotional mental health of respondents.

Keywords: emotional mental health, psychological, social culture, somatic

Korespondensi: Tunjung S. Yulianti. STIKES PANTI KOSALA SURAKARTA, Jalan Raya Solo - Baki KM. 4 Gedangan, Grogol, Sukoharjo, Jawa Tengah.

Email: tejeyulianti@gmail.com.

\section{LATAR BELAKANG}

Hasil Riset Kesehatan Dasar menyatakan kesehatan jiwa masih menjadi salah satu permasalahan kesehatan yang signifikan di dunia, termasuk di Indonesia (Depkes, 2013). Menurut data Word Health Organization (2016), terdapat sekitar 35 juta orang terkena depresi, 60 juta orang terkena bipolar, 21 juta terkena skizofrenia, serta 47,5 juta terkena demensia. Di Indonesia, dengan berbagai faktor biologis, psikologis dan sosial dengan keanekaragaman penduduk, maka jumlah kasus gangguan jiwa terus bertambah yang berdampak pada penambahan beban negara dan penurunan produktivitas manusia untuk jangka panjang. Data Riset Kesehatan Dasar (Depkes, 2013) menunjukkan prevalensi ganggunan mental emosional yang ditunjukkan dengan gejala-gejala depresi dan kecemasan untuk usia 15 tahun ke atas mencapai sekitar 14 juta orang atau $6 \%$ dari jumlah penduduk Indonesia. Sedangkan prevalensi gangguan jiwa berat, seperti skizofrenia mencapai sekitar 400.000 orang atau sebanyak 1,7 per 1.000 penduduk.

Menurut Undang-Undang Kesehatan Jiwa No 18 tahun 2014 kesehatan jiwa adalah kondisi dimana seorang individu dapat berkembang secara fisik, mental, spiritual, dan sosial sehingga individu tersebut menyadari kemampuan sendiri, dapat mengatasi tekanan, dapat bekerja secara produktif, dan mampu memberikan kontribusi untuk komunitasnya. Umumnya manusia memiliki kemampuan untuk menyesuaikan diri dengan baik, mampu berfikir secara rasional, mampu menghadapi lingkungan secara efektif, serta mampu mengatur dan mengendalikan emosi secara efektif.

Di era globalisasi dan modernisasi akibat kemajuan teknologi membawa perubahan gaya hidup masyarakat modern dan perubahan dalam cara berfikir. Perubahan tersebut akan membawa konsekuensi di bidang kesehatan jiwa karena tidak semua orang mampu menyesuaikan diri, akibatnya akan menimbulkan ketegangan dan kecenderungan peningkatan gangguan kesehatan jiwa (Azizah, Zainuri dan Akbar, 2016). Jika seseorang mengalami perubahan fisik atau tingkah laku, menurunnya semua fungsi kejiwaan seperti proses berfikir, emosi dan kemauan dalam memperoleh sesuatu itu merupakan salah satu bentuk penyimpangan perilaku dalam gangguan jiwa. Keliat (2011) menjelaskan gangguan jiwa merupakan suatu perubahan pada fungsi jiwa yang menyebabkan adanya gangguan pada fungsi jiwa, penderitaan pada individu dan atau hambatan dalam melaksanakan peran sosial. Menurut Yosep dan Sutini (2014) sumber penyebab gangguan jiwa dipengaruhi oleh faktor dari ketiga unsur yaitu somatogenik (badan), sosiogenik (sosial) dan psikogenik (psikologis). Biasanya tidak terdapat penyebab tunggal, akan tetapi beberapa penyebab sekaligus dari berbagai 
unsur tersebut saling mempengaruhi atau kebetulan terjadi bersamaan.

Penelitian Rinawati dan Alimansur (2016) tentang analisa faktor-faktor penyebab gangguan jiwa menggunakan pendekatan adaptasi stres Stuart, disimpulkan bahwa kesehatan jiwa merupakan bagian yang tidak terpisahkan dari kesehatan secara umum serta merupakan dasar bagi pertumbuhan dan perkembangan manusia. Penyebab gangguan jiwa terdiri dari faktor predisposisi dan presipitasi. Faktor ini ditinjau dari aspek biologis, psikologis dan sosial. Faktor predisposisi terbanyak pada aspek biologis adalah pernah mengalami gangguan jiwa sebelumnya 32 responden $(36,2 \%)$, pada aspek psikologis adalah tipe kepribadian 39 responden $(29,4 \%)$ dan penyebab pada aspek sosial adalah klien tidak bekerja 41 responden $(23,8 \%)$, sedangkan faktor presipitasi, penyebab pada aspek biologis terbanyak adalah putus obat 32 responden $(69,6 \%)$, penyebab pada aspek psikologis terbanyak adalah pengalaman tidak menyenangkan 21 responden $(45,8 \%)$ dan penyebab pada aspek sosial terbanyak adalah konflik dengan keluarga atau teman 17 responden (37\%). Sedangkan penelitian Yanuar (2012) tentang Faktor yang Berhubungan dengan Kejadian Gangguan Jiwa di Desa Paringan Kecamatan Jenangan Kabupaten Ponorogo dengan hasil faktor genetik $(p=0,030)$, kepribadian $(p=0,033)$ dan konsep diri $(p=0,033)$ memiliki pengaruh besar untuk menentukan terjadinya gangguan mental. Jenis pekerjaan $(p=0,777)$, dukungan keluarga $(p=0$, $593)$, tingkat pendidikan $(p=0,871)$, dan pendapatan nominal $(p=0,848)$, bukan merupakan penyebab gangguan mental.

Dusun Gumuk Sari dan Gerjen berada dalam satu kebayanan yaitu Kebayanan I di Kelurahan
Pucangan Kecamatan Kartasura Kabupaten Sukoharjo. Di Dukuh Gumuk Sari maupun Gerjen kondisi ekonomi penduduk rata-rata cukup baik, hampir semua penduduk bekerja dan berpenghasilan cukup. Hubungan sosial di Dukuh Gerjen sangat baik, banyak kegiatan masyarakat yang dilakukan setiap minggu, sementara di Dukuh Gumuk Sari jarang ada pertemuan warga. Terdapat warga yang menunjukkan gejala gangguan kesehatan jiwa di kedua dukuh tersebut.

\section{TUJUAN PENELITIAN}

Mengetahui faktor-faktor yang mempengaruhi kesehatan mental emosional masyarakat di Dukuh Gumuk Sari dan Gerjen, Pucangan, Kartasura.

\section{METODE}

Penelitian ini merupakan penelitian analitik dengan desain korelasi untuk mengetahui faktor-faktor yang mempengaruhi kesehatan mental emosional masyarakat. Data dianalisis menggunakan analisis multivariat yaitu uji Regresi Logistik Ganda.

\section{SUBJEK}

Populasi pada penelitian ini adalah warga Dusun Gumuk Sari dan Gerjen. Dengan quota sampling diperoleh sampel 219 orang yang terdiri dari Dusun Gumuk Sari 92 orang dan Dusun Gerjen 127 orang.

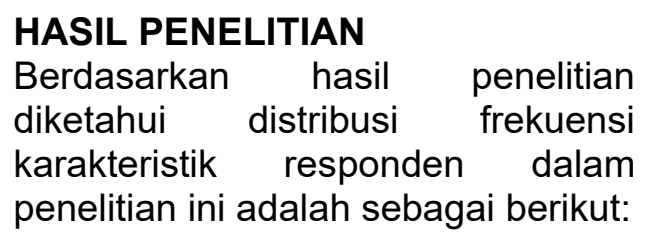


Tabel 1.

Distribusi Frekuensi

Karakteristik Responden

\begin{tabular}{lcc}
\hline Karakteristik & $\mathrm{f}$ & $\%$ \\
\hline Jenis Kelamin & & \\
Laki-laki & 99 & 45,2 \\
Perempuan & 120 & 54,8 \\
Umur & & \\
$<30$ tahun & 36 & 16,4 \\
$31-60$ tahun & 159 & 72,6 \\
$>60$ tahun & 24 & 11 \\
Pendidikan & & \\
SD & 23 & 10,5 \\
SMP & 23 & 10,5 \\
SMA & 99 & 45,2 \\
Sarjana & 74 & 33,8 \\
\hline
\end{tabular}

Distribusi frekuensi karakteristik pada setiap variabel adalah sebagai berikut:

Tabel 2.

Distribusi Frekuensi Variabel Dependen

\begin{tabular}{lcc}
\hline Variabel & $\mathrm{f}$ & $\%$ \\
\hline Faktor Somatik & & \\
Ada & 25 & 11,4 \\
Tidak Ada & 194 & 88,6 \\
Faktor psikologis & & \\
Ada & 25 & 11,4 \\
Tidak ada & 194 & 88,6 \\
Faktor Sos-bud & & \\
Ada & 25 & 11,4 \\
Tidak ada & 194 & 88,6 \\
\hline
\end{tabular}

Tabel 3.

Distribusi Frekuensi Kesehatan Mental

\begin{tabular}{lcc}
\hline $\begin{array}{l}\text { Kesehatan Mental } \\
\text { Emosional }\end{array}$ & $\mathrm{f}$ & $\%$ \\
\hline Mengalami & 45 & 20,5 \\
Tidak mengalami & 174 & 79,5 \\
Jumlah & 219 & 100 \\
\hline
\end{tabular}

Hasil analisis bivariat dapat disajikan sebagai berikut:

Tabel 4. Tabulasi Silang

\begin{tabular}{lccc}
\hline & \multicolumn{2}{c}{ Kesehatan Mental } & \\
\cline { 2 - 3 } Kategori & $\begin{array}{c}\text { Mengalami } \\
\mathrm{n}=45\end{array}$ & $\begin{array}{c}\text { Tidak } \\
\text { mengalami } \\
\mathrm{n}=174\end{array}$ & $\mathrm{p}$ \\
\hline Somatik & 23 & 2 & \\
Ada & $(10,5)$ & $(0,9)$ & 0,001 \\
Tidak & 22 & 172 & \\
Ada & $(10,1)$ & $(78,5)$ & \\
Psikologi & & & \\
Ada & 18 & 7 & 0,001 \\
Tidak & $(8,2)$ & $(3,2)$ & \\
Ada & 27 & 167 & \\
Sos-Bud & $(12,3)$ & $(76,3)$ & \\
Ada & 19 & 6 & 0,001 \\
Tidak & $(8,7)$ & $(2,7)$ & \\
Ada & 26 & 168 & \\
\hline & $(11,9)$ & $(76,7)$ & \\
\hline
\end{tabular}

Dari tabel di atas, jumlah responden yang memiliki masalah pada faktor somatik dan mengalami gejala gangguan kesehatan mental emosional sebanyak 23 orang $(10,5 \%)$. Responden yang memiliki masalah pada faktor psikologis dan mengalami gejala gangguan kesehatan mental emosional sebanyak 18 orang $(8,2 \%)$. Responden yang memiliki masalah terkait sosial budaya dan mengalami gangguan mental emosional sebanyak 19 orang $(8,7 \%)$.

Hasil analisa bivariat terhadap ketiga variabel diperoleh nilai $p=$ 0.001 , sehingga dapat disimpulkan bahwa ketiga variabel bebas semuanya memiliki pengaruh terhadap variabel terikat sehingga memenuhi syarat untuk dilakukan analisa lebih lanjut dengan multivariat.

Hasil analisis multivariat dapat disajikan sebagai berikut: 
Tabel 5.

Analisis Multivariat Faktor Somatik, Psikologi, Sosial Budaya dan Kesehatan Mental Emosional

\begin{tabular}{lccrl}
\hline & \multicolumn{4}{c}{ Nilai } \\
\cline { 2 - 5 } Variabel & B & Sig & $\begin{array}{r}\text { Exp } \\
\text { (B) }\end{array}$ & $\begin{array}{l}\text { Nagel } \\
\text { kerke R } \\
\text { Square }\end{array}$ \\
\hline $\begin{array}{l}\text { Faktor } \\
\text { somatik }\end{array}$ & 3,926 & 000 & $50,708,526$ \\
\hline $\begin{array}{l}\text { Faktor } \\
\text { psikologis }\end{array}$ & 1,335 &, 058 & 3,800 \\
\hline $\begin{array}{l}\text { Faktor } \\
\text { sosbud }\end{array}$ & 1,954 &, 004 & 7,054 \\
\hline
\end{tabular}

Dari tabel di atas dapat diketahui bahwa secara bersama-sama faktor somatik, faktor psikologis dan faktor sosial budaya mempunyai pengaruh terhadap gangguan mental emosional. Dilihat dari nilai Nagelkerke $R$ Square pengaruhnya sebesar 52,6\%. Nilai OR untuk faktor somatik sebesar 50,708 , faktor sosial budaya sebesar 7,054 dan faktor psikologis sebesar 3,800 .

\section{PEMBAHASAN}

Data menunjukkan dari analisis bivariat maupun multivariat terhadap faktor somatik diperoleh nilai $p=$ 0,001 . Hasil ini menunjukkan bahwa faktor somatik memiliki pengaruh signifikan terhadap kesehatan mental emosional responden. Faktor somatik dalam penelitian ini adalah kondisi yang berupa gangguan fisik atau penyakit yang dapat mempengaruhi kesehatan mental emosional. Dari data diketahui bahwa jumlah responden yang memiliki masalah pada faktor somatik lebih banyak yang mengalami gejala gangguan kesehatan mental emosional yaitu 23 orang $(10,5 \%)$.

Faktor somatik atau aspek biologis memiliki peran dalam menyebabkan gangguan jiwa pada seseorang. Kondisi mental emosional atau keseimbangan jiwa yang terganggu akibat kondisi tubuh atau gangguan fisik biasanya diawali dengan munculnya perasaan rendah diri. Hal tersebut sesuai dengan paparan dari Yosep dan Sutini (2014) bahwa faktor presipitasi dari harga diri rendah biasanya adalah kehilangan bagian tubuh atau perubahan penampilan/bentuk tubuh, kegagalan atau produktivitasnya menurun. Selain rasa rendah diri akibat masalah pada fisiknya, seseorang dengan penyakit kronis/menahun atau penyakit berat/terminal juga akan mengalami masalah mental emosional. Individu tersebut dapat mengalami depresi. Hal tersebut sesuai dengan paparan dari Sutejo (2017) bahwa gangguan harga diri kronis biasanya terjadi karena adanya kondisi sakit fisik yang dapat mempengaruhi kerja hormon secara umum. Hal ini juga berdampak pada keseimbangan neurotransmitter di otak, seperti menurunnya kadar serotonin yang dapat mengakibatkan klien mengalami depresi. Yosep dan Sutini (2014) juga memaparkan bahwa penyakit fisik terutama penyakit kronis dan terminal serta cidera merupakan salah satu sumber stress yang dapat menimbulkan depresi dan kecemasan.

Hasil statistik multivariat untuk variable somatik menunjukkan nilai $\mathrm{B}=3,296$, Sig $=0,001$ dan OR = 50,708 . Berdasarkan hasil statistik tersebut dapat kita lihat bahwa faktor somatik mempunyai korelasi positif terhadap kesehatan mental emosional, semakin tinggi/banyak gangguan somatik maka semakin tinggi resiko mengalami masalah kesehatan mental emosional yaitu sebesar 50,708. Hasil ini senada dengan penelitian analisis lanjut dari data Riskesdas tahun 2007 yang dikutip oleh Wardhani, et al. (2016), tentang pelayanan kesehatan mental dalam hubungannya dengan disabilitas dan gaya hidup masyarakat Indonesia, yang 
menunjukkan hasil terdapat asosiasi (hubungan) yang bermakna antara disabilitas dan gangguan mental emosional. Kondisi ini dapat dipahami karena seseorang yang mengalami disabilitas fisik dan disabilitas sosial akan dapat mempengaruhi kondisi kejiwaan mereka. Bahwa kondisi fisik dapat menyebabkan persoalan mental dan sebaliknya masalah/kesulitan mental dapat memperburuk gejala fisik. Hasil penelitian lain yang menguatkan adalah penelitian yang dilakukan oleh Widakdo, Giri dan Besral (2013) tentang efek penyakit kronis terhadap gangguan mental emosional dimana diperoleh hasil responden yang menderita satu penyakit kronis beresiko 2,6 kali lebih besar untuk mengalami gangguan mental emosional, begitu juga yang menderita dua penyakit kronis beresiko 4,6 kali dan yang menderita tiga penyakit kronis atau lebih beresiko 11 kali.

Data penelitian ini juga menunjukkan hal lain, dimana responden yang tidak memiliki masalah pada faktor somatik tetapi mengalami gangguan mental emosional sebanyak 22 orang $(10,1 \%)$. Hal ini menunjukkan bahwa gangguan mental emosional yang dialami responden mungkin dipengaruhi oleh faktor yang lain. Karena gangguan jiwa dapat disebabkan oleh multi faktor seperti yang dipaparkan oleh Yosep dan Sutini (2014) bahwa sumber penyebab gangguan jiwa dipengaruhi oleh faktor dari ketiga unsur yaitu somatogenik (badan), sosiogenik (sosial) dan psikogenik (psikologis). Data ini senada dengan hasil penelitian Rinawati dan Alimansur (2016) tentang Analisa Faktor-Faktor Penyebab Gangguan Jiwa menggunakan Pendekatan Adaptasi Stres Stuart, disimpulkan bahwa penyebab gangguan jiwa terdiri dari faktor predisposisi dan presipitasi. Faktor ini ditinjau dari aspek biologis, psikologis dan sosial. Faktor predisposisi terbanyak pada aspek biologis adalah klien pernah mengalami gangguan jiwa sebelumnya $(36,2 \%)$, pada aspek psikologis adalah tipe kepribadian $(29,4 \%)$ dan penyebab pada aspek sosial adalah klien tidak bekerja $(23,8 \%)$, sedangkan faktor presipitasi, penyebab pada aspek biologis terbanyak adalah putus obat $(69,6 \%)$, penyebab pada aspek psikologis terbanyak adalah pengalaman tidak menyenangkan $(45,8 \%)$ dan penyebab pada aspek sosial terbanyak adalah konflik dengan keluarga atau teman (37\%). Untuk faktor sosial budaya hasil analisa bivariat diperoleh nilai $p=$ 0,001 , sedangkan dari analisis multivariat diperoleh nilai $p=0,004$. Hasil tersebut menunjukkan bahwa faktor sosial budaya memiliki pengaruh terhadap kesehatan mental emosional responden. Faktor sosial budaya adalah faktor yang berupa gangguan nilai, tata sosial dan tata laku manusia yang dapat mempengaruhi kesehatan mental emosional masyarakat. Dari data diketahui bahwa jumlah responden yang memiliki masalah pada faktor sosial budaya lebih banyak yang mengalami gejala gangguan kesehatan mental emosional yaitu 19 orang $(8,7 \%)$.

Menurut teori dari Caplan dan Szasz yang dikutip oleh Yosep dan Sutini (2014) seseorang akan mengalami gangguan jiwa atau penyimpangan perilaku apabila banyak faktor sosial dan faktor lingkungan yang akan memicu munculnya stress pada seseorang. Stresor lingkungan misalnya kebisingan, tuntutan pekerjaan, polusi, sampah dan lainlain. Stressor dari lingkungan diperparah oleh stressor dalam hubungan sosial misalnya masalah dengan teman kerja, atasan, masalah dengan pasangan, tetangga, sekolah, guru yang mengancam dan lain-lain. Teori dari 
Stuart yang dikutip oleh Yosep dan Sutini (2014) juga menjelaskan bahwa stress dapat timbul dari kondisi kronis diantaranya adalah masalah dalam keluarga yang berlangsung terus menerus, ketidakpuasan dalam pekerjaan dan kesendirian. Pada umumnya stressor terjadi pada perkawinan, problem orangtua, hubungan interpersonal, pekerjaan, lingkungan hidup, keuangan, hukum, perkembangan, faktor keluarga dan lain-lain.

Hasil statistik multivariat menunjukkan nilai $B=1,954$, Sig $=$ 0,004 dan $\mathrm{OR}=7,054$. Berdasarkan hasil statistik tersebut dapat kita lihat bahwa faktor sosial budaya mempunyai korelasi positif terhadap kesehatan mental emosional, yaitu semakin tinggi/banyak masalah sosial budaya maka semakin tinggi resiko mengalami gangguan kesehatan mental emosional yaitu sebesar 7,054 kali. Hasil ini sesuai dengan penelitian yang dilakukan oleh Suerni dan Livana (2019) tentang gambaran faktor predisposisi pasien isolasi sosial dimana diperoleh hasil bahwa salah satu faktor predisposisi adalah faktor sosial budaya yaitu perasaan terintimidasi oleh lingkungan sekolah, sosial dan pekerjaan. Penelitian serupa yang dilakukan oleh Utomo (2013) tentang hubungan antara faktor somatik, psikososial dan sosial-kultural dengan kejadian skizofrenia memperoleh hasil yang senada yaitu ada hubungan antara faktor sosial-kultural dengan kejadian skizofrenia dan responden yang mengalami masalah pada faktor sosial-kultural beresiko 3 kali terkena skizofrenia daripada yang tidak memiliki faktor resiko tersebut.

Dari paparan di atas dapat dipahami bila hasil yang ditemukan menunjukkan pengaruh faktor sosial budaya terhadap kesehatan mental emosional responden. Seperti kita ketahui bahwa pada era globalisasi dan persaingan bebas ini kecenderungan terhadap peningkatan gangguan jiwa semakin besar, hal ini disebabkan karena stresor dalam kehidupan semakin kompleks yang meningkatkan resiko timbulnya masalah pada kesehatan mental emosional masyarakat.

Akan tetapi dari analisa data juga ditemukan responden yang tidak memiliki masalah pada faktor sosial budaya tetapi mengalami gangguan mental emosional sebanyak 26 orang $(1,9 \%)$. Hal ini sesuai dengan paparan yang telah disampaikan sebelumnya bahwa kesehatan mental emosional dipengaruhi oleh multifaktor. Yosep dan Sutini (2014) memaparkan bahwa manusia bereaksi secara keseluruhan, secara holistik atau secara somatopsiko-sosial. Dalam mencari penyebab gangguan jiwa, maka ketiga unsur ini harus diperhatikan. Untuk faktor psikologi, berdasarkan analisa bivariat menunjukkan pengaruh yang signifikan terhadap kesehatan mental emosional dengan nilai $p=0,001$. Setelah dianalisis bersama-sama dengan faktor somatik dan sosial budaya diperoleh nilai $p=0,058$ dan OR = 3,800 . Sehingga dapat diambil kesimpulan bahwa pada penelitian ini yang paling berpengaruh pada kesehatan mental emosional adalah faktor somatik sebesar 50,708, dan faktor sosial budaya sebesar 7,054. Sedangkan faktor psikologis secara bersama-sama dengan faktor somatik dan sosial budaya memiliki pengaruh yang paling kecil terhadap kesehatan mental emosional responden yaitu sebesar 3,800 .

Hasil ini sangat mungkin dipengaruhi oleh usia dan tingkat pendidikan responden. Dari data yang diperoleh, sebagian besar responden berusia antara 31-60 tahun $(72,6 \%)$, berpendidikan SMA $(45,2 \%)$ dan Sarjana $(33,8 \%)$. Dari segi usia, sebagian besar 
responden berada pada usia 31-60 tahun yang masuk pada kategori dewasa tengah. Menurut Schie sebagaimana dikutip oleh Mar'at (2015) pada usia ini biasanya nilai pemeliharaan berkembang yang terungkap dalam kepedulian kepada orang lain, keinginan memberikan perhatian, berbagi pengetahuan dan pengalaman bagi yang membutuhkan. Hal ini membuat orang dewasa merasa dibutuhkan dan memiliki arti yang membuat mereka tidak terlalu asyik dan larut dengan diri mereka sendiri. Orang dewasa yang berusia antara 40 tahun sampai dengan awal 60 tahun adalah orang-orang yang suka instrospeksi, banyak berbuat sesuatu untuk sisa waktu hidupnya. Orang dalam usia ini secara mental juga akan mempersiapkan diri untuk sewaktu-waktu menghadapi persoalan yang terjadi. Dari paparan di atas dapat dipahami apabila responden memiliki kesiapan mental yang baik untuk menghadapi persoalan hidupnya karena sebagian besar responden berada pada usia dewasa.

Sedangkan dari faktor pendidikan, sebagian besar responden memiliki tingkat pendidikan SMA $(45,2 \%)$ dan sarjana $(33,8 \%)$. Dari data tersebut menunjukkan tingkat pendidikan responden cukup baik. Menurut Wawan dan Dewi (2010) pendidikan dapat mempengaruhi perilaku seseorang, pada umumnya makin tinggi tingkat pendidikan seseorang maka makin mudah menerima informasi. Berdasarkan paparan di atas dapat dipahami bila orang dengan pendidikan tinggi lebih memiliki wawasan yang luas, memahami dan memiliki pola hidup sehat, mengetahui cara menyelesaikan masalah, dan cara mengaktualisasikan potensi diri. Dalam hal ini responden yang sebagian besar memiliki tingkat pendidikan yang tinggi akan mampu mengatasi problema kehidupan yang dihadapinya. Pendidikan yang cukup baik juga akan berkontribusi pada kepercayaan diri seseorang. Kepercayaan diri yang tinggi ini akan berdampak pada harga diri seseorang. Menurut Yosep dan Sutini (2014) individu yang memiliki harga diri tinggi mampu menghadapi lingkungan secara aktif dan mampu beradaptasi secara efektif untuk berubah serta cenderung merasa aman.

Dari paparan di atas dapat dipahami bila usia dewasa dan tingkat pendidikan yang dimiliki responden dapat berkontribusi terhadap kesiapan responden dalam beradaptasi dengan lingkungan dan menghadapi masalah-masalah yang mungkin muncul dalam hidupnya sehingga memiliki ketahanan psikologis yang baik.

Data dalam penelitian ini juga menunjukkan responden yang tidak memiliki masalah pada faktor psikologis tetapi mengalami gangguan mental emosional sebanyak 27 orang $(12,3 \%)$. Hal ini bisa dipahami karena biasanya tidak terdapat penyebab tunggal, akan tetapi beberapa penyebab sekaligus dari berbagai unsur tersebut saling mempengaruhi atau kebetulan terjadi bersamaan. Reponden mungkin tidak memiliki masalah pada faktor psikologis akan tetapi memiliki masalah pada faktor somatik atau sosial budayanya ataupun sebaliknya sehingga hal tersebut mempengaruhi kesehatan mental emosionalnya. Dari uraian di atas dapat dipahami apabila dalam penelitian ini juga ditemukan responden yang tidak mengalami masalah psikologis tetapi mengalami gangguan kesehatan mental emosional.

Berdasarkan paparan pada pembahasan di atas dapat diketahui bahwa dalam penelitian ini terdapat beberapa faktor yang berpengaruh terhadap kesehatan mental emosional. Secara bersama-sama 
dengan faktor sosial budaya dan faktor psikologis, faktor somatik adalah faktor yang memiliki pengaruh paling besar untuk meningkatkan resiko mengalami gangguan mental emosional pada masyarakat. Keluhan somatik, penyakit kronis atau penyakit terminal menjadi stresor yang dapat menyebabkan kecemasan dan depresi. Menurut Hawari (2011) setiap permasalahan kehidupan yang menimpa pada diri seseorang (stresor psikososial) dapat mengakibatkan gangguan fungsi/faal organ tubuh. Reaksi tubuh ini dinamakan stres, manakala fungsi organ tubuh sampai terganggu dinamakan distres. Depresi merupakan reaksi kejiwaan seseorang terhadap stres yang dihadapinya. Oleh karena dalam diri manusia itu antara fisik dan psikis tidak dapat dipisahkan satu sama lain dan saling mempengaruhi. Serangan yang terjadi pada gangguan jiwa biasanya berupa perasaan khawatir berlebihan terhadap hampir semua aspek kehidupan, perasaan lelah berlebihan yang tidak disebabkan karena faktor kelelahan fisik, iritabel atau mudah tersinggung, dan gejala fisik seperti kaku otot, pegal-pegal, gangguan tidur atau sulit merasa santai. Ketika penderita mengalami gangguan tersebut terkadang penderita mengabaikannya yang berakibat pada bertambah parahnya gangguan yang dialami oleh penderita. Oleh karena itu diperlukan adanya upaya peningkatan pemahaman masyarakat untuk mencegah terjadinya gangguan jiwa tersebut.

\section{KESIMPULAN}

Terdapat beberapa faktor yang berpengaruh terhadap kesehatan mental emosional. Secara bersamasama faktor somatik adalah faktor yang memiliki pengaruh paling besar untuk meningkatkan resiko mengalami gangguan mental emosional pada masyarakat dengan nilai $p=0,001$ dan OR 50,708. Faktor sosial budaya berpengaruh terhadap kesehatan mental emosional dengan nilai $p=0,004$ dan OR 7,054. Sedangkan faktor psikologik berpengaruh terhadap kesehatan mental emosional dengan nilai $p=0,058$ dan $\mathrm{OR}=3,800$.

\section{SARAN}

Puskesmas (Community Mental Health Nurse) membentuk kader kesehatan jiwa masyarakat dengan memberikan pelatihan terkait dengan masalah kesehatan jiwa masyarakat, selanjutnya kader memberikan perhatian terhadap faktor resiko gangguan mental emosional terutama faktor somatik dengan cara memberikan support atau pendampingan terhadap warga yang memiliki penyakit kronis atau terminal dan mengoptimalkan dukungan keluarga, serta berkoordinasi dengan perangkat dan tokoh masyarakat dalam mewujudkan desa siaga sehat jiwa.

\section{DAFTAR PUSTAKA}

Azizah, L. M., I. Zainuri dan A. Akbar. 2016. Buku Ajar Keperawatan Kesehatan Jiwa. Teori dan Aplikasi Praktik Klinik. Indomedika Pustaka, Yogyakarta.

Depkes RI. 2013. Laporan Hasil Riset Kesehatan Dasar (RIKESDAS) Nasional. Badan Penelitian dan Pengembangan DEPKES RI, Jakarta.

Hawari, D. 2011. Manajemen Stres, Cemas dan Depresi. Fakultas Kedokteran Universitas Indonesia, Jakarta.

Keliat, B. A. 2011. Keperawatan Kesehatan Jiwa Komunitas. EGC, Jakarta.

Mar'at, S. 2015. Psikologi Perkembangan. PT Remaja Rosdakarya, Bandung. 
Rinawati, F. dan M. Alimansur. 2016. "Analisis Faktor-faktor Penyebab Gangguan Jiwa Menggunakan Pendekatan Model Adaptasi Stress Stuart". Jurnal IImu Kesehatan. Edisi V. Kediri. Diakses pada tanggal 24 April 2019.

Suerni, T. dan Livana P.H. 2019. "Gambaran Faktor Predisposisi Pasien Isolasi Sosial". Jurnal Keperawatan. Diunduh pada tanggal 13 April 2020.

Sutejo. 2017. Keperawatan Kesehatan Jiwa. Pustaka Baru Press, Yogyakarta.

Utomo, T. L. 2013. "Hubungan Antara Faktor Somatik, Psikososial dan Sosio-Kultur dengan Kejadian Skizofrenia". Thesis. Universitas Muhammadiyah Surakarta. Diunduh pada tanggal 13 April 2020.

Wardhani, Y. Fauziah, Paramita dan Astridya. 2016. "Pelayanan Kesehatan Mental dalam Hubungannya dengan Disabilitas dan Gaya Hidup Masyarakat Indonesia". Buletin Penelitian Sistem Kesehatan. Diunduh pada tanggal 13 April 2020.
Wawan, A. dan M. Dewi. 2010. Teori dan Pengukuran Pengetahuan, Sikap dan Perilaku Manusia, Nuha Medika, Yogyakarta.

World Health Organization (WHO). (2016). Mental Health. http://www.who.int/mental_heal th/en/ Diakses tanggal 24 April 2019

Widakdo, Giri dan Besral. 2013. "Efek Penyakit Kronis terhadap Gangguan Mental Emosional". Jurnal Kesehatan Masyarakat. Diunduh pada tanggal 13 April 2020.

Yanuar, R. 2012. "Analisis FaktorFaktor yang Berhubungan dengan Kejadian Gangguan Jiwa di Desa Paringan Kecamatan Jenangan Kabupaten Ponorogo. Jurnal IImu Kesehatan Masyarakat. Diunduh pada tanggal 25 April 2019.

Yoseph, H. I dan T. Sutini. 2014. Buku Ajar Keperawatan Jiwa dan Advance Mental Health Nursing. PT Refika Aditama, Bandung. 